\title{
Cytomegalovirus infection in non-immunosuppressed critically ill patients
}

\author{
Manisha Jain ${ }^{1}$, Shalini Duggal ${ }^{2}$, Tulsi Das Chugh $^{2}$ \\ ${ }^{1}$ Department of Microbiology, G. B. Pant Hospital, Delhi, India \\ ${ }^{2}$ Department of Microbiology, B. L. Kapur Memorial Hospital, Delhi, India
}

\begin{abstract}
Cytomegalovirus (CMV) is an important and common cause of mortality and morbidity in immunocompromised patients such as those with HIV/AIDS, transplant recipients on immunosuppressive therapy, and malignant hematological disease. After primary infection with CMV the virus becomes latent in multiple organs and can later be reactivated during severe dysregulation of the immune system. A large population carry dormant virus and are thus at risk for reactivation.

However, reactivation of CMV has been reported in "non-immunosuppressed patients" such as severe trauma, sepsis, shock, burns, cirrhosis and other critically ill patients lying in the intensive care units. Therefore, the intensivists are increasingly facing a dilemma of identifying such patients to treat and there is a debate if there is a scientific justification for prophylaxis in such immunocompetent patients.
\end{abstract}

Key words: CMV; reactivation; critically ill; ICU patients

J Infect Dev Ctries 2011; 5(8):571-579.

(Received 11 August 2010 - Accepted 27 March 2011)

Copyright (C) 2011 Jain et al. This is an open-access article distributed under the Creative Commons Attribution License, which permits unrestricted use, distribution, and reproduction in any medium, provided the original work is properly cited.

\section{Introduction}

Cytomegalovirus (CMV) is an important and common cause of mortality and morbidity in immunocompromised patients such as those with HIV/AIDS, transplant recipients on immunosuppressive therapy, and malignant hematological disease. After primary infection with CMV the virus becomes latent in multiple organs and can later be reactivated during severe dysregulation of the immune system. A large population carry dormant virus and are thus at risk for reactivation.

However, reactivation of CMV has been reported in "non-immunosuppressed patients" such as severe trauma, sepsis, shock, burns, cirrhosis and other critically ill patients lying in the intensive care units. Therefore, the intensivists are increasingly facing a dilemma of identifying such patients to treat and there is a debate if there is a scientific justification for prophylaxis in such immunocompetent patients

\section{Review of literature}

Cytomegalovirus (CMV) is the prototype member of Betaherpesvirinae in the subfamily Herpesviridae. The structure of CMV is similar to other members of Herpesviridae. It is an enveloped virus with icosahedral symmetry containing a large genome of double stranded DNA. CMV has the largest genome of around $235 \mathrm{~kb}$ encoding for over 200 genes [1].

CMV has a longer replication cycle and it encodes for a diverse array of gene products, many of which play an immunomodulatory role in the host. Its genome codes sequentially for three genes, which encode for immediate early, early and late proteins respectively. The immediate early (IE) proteins are regulatory and the late proteins are structural. Many late proteins such as pp65 antigen have antigenic properties which can be used for diagnosis of CMV infection.

\section{Pathogenesis and immunological basis}

Primary CMV infection is not a problem in these critically ill immunocompetent patients. The most common mechanism proposed for CMV infection or disease in such critically ill patients is as a result of reactivation of CMV virus and not primarily due to primary infection. CMV has the ability to establish latency in various different types of cells unlike other herpes viruses which largely remain localized $[2,3]$. Monocytes, CD 34+ haematopoietic progenitor cells, and endothelial cells are the major sites where latent CMV is present.

There are diverse mechanisms by which CMV is able to avoid immunosurveillance and establish 
persistence in host cells. T cells and NK cells play a central role in controlling CMV infection and hence reactivation of $\mathrm{CMV}$ in immunocompetent persons is rare. CMV possesses a series of genes by which it escapes the defense immunity. Genes expressed in the unique short (US) region of CMV inhibit the expression of human leucocyte antigen (HLA) class I molecules and interfere with the antigen presentation in the infected cells. Thus the viral antigens are not recognized and they escape the cytotoxic CD $8+T$ cells. Decreased expression of HLA makes the cells susceptible to lysis by NK cells and this is prevented by expression of proteins in the unique long region of CMV.

CMV has also devised mechanisms to avoid immunosurveillance by CD4+ T cells. It is seen that expression of HLA Class II is impaired in CMV infected cells. Though this is an oversimplified explanation, these escape mechanisms devised by CMV help it to maintain latency without being eliminated by the immune mechanisms [2,3]. Immunosuppression in the host for any reasons leads to replication of the virus which was kept in check by the immune mechanisms.

There is a high level of complexity between the virus and the host. The exact mechanisms of its reactivation are still not clear and many other mechanisms besides immune mediated have been implicated in the reactivation of CMV [4,5].

Reactivation is a multifactorial and multistep process. The activation of the IE region is seen as the first crucial step for reactivation of CMV. These IE enhancer/promoter sequences contain various nuclear factor kappa $\mathrm{B}(\mathrm{NF}-\kappa \mathrm{B})$ consensus sequences which are normally inactive [5].

It is thus postulated that any mediator or signal activating NF- $\mathrm{BB}$ is capable of triggering CMV reactivation. There are diverse stimuli which can activate NF- $\kappa \mathrm{B}$ and in turn activate CMV. These include proinflammatory cytokines, chemokines, adhesion molecules, inflammatory enzymes, and receptors which are released during sepsis, burns, surgery, trauma, multiple organ failure syndrome, allogeneic blood transfusions, or organ and bone marrow transplants $[5,6,7,8]$. It was seen that the proinflammatory cytokine TNF- $\alpha$ induces activation of protein kinase $\mathrm{C}$ and nuclear factor $\kappa \mathrm{B}$. These changes in turn result in expression of the IE gene thus initiating the replication cycle of CMV [5,7].

CMV lies latent in monocytes in which no viral gene is expressed. When these monocytes are differentiated into macrophages, as occurs during inflammatory conditions such as sepsis, burns, trauma and surgery, the viral genes are expressed and viral replication is initiated [5,7,8]. Thus theoretically in patients critically ill as a result of sepsis, trauma, burns and other conditions, CMV gets reactivated bypassing the immune mechanisms.

In addition to the direct harmful effects of CMV, many indirect effects have been recognized in the host cell [9]. Replication of CMV causes tissue injury. This leads to release of proinflammatory cytokines which causes low-grade chronic inflammatory changes or even exacerbation of certain preexisting diseases such as inflammatory bowel disease in the host.

CMV leads to a direct procoagulant activity in the host tissue because of its ability to directly invade vascular endothelial cells. It also causes activation of vascular cells which in turn increases expression of adhesion molecules. These adhesion molecules then react with platelets and leucocytes to cause a hypercoagulable state. These effects lead to thrombotic complications in the host. The virus also causes inhibition of progenitor haematopoietic cells and thus suppresses haematopoiesis in the host [10].

CMV infection can itself accelerate immune responses thus exacerbating graft versus host reactions. In experimental animal models it was observed that there was enhanced rejection of allogeneic transplants as a result of accelerated immune response by CMV infection [11].

\section{Epidemiology}

CMV is endemic in most areas of the world. The seroprevalence of CMV varies in different geographical areas and it ranges from 30-100\% [1,9]. CMV infection is usually asymptomatic in immunocompetent persons. Reactivation of CMV has been of concern in immunosuppressed individuals as it is associated with adverse clinical outcomes. CMV reactivation in apparently immunocompetent individuals with critical illness is becoming an area of emerging clinical significance. It has been observed that CMV infection occurs in critically sick patients admitted in ICUs and the prevalence ranges from $0-35 \%$ [12-17]. This wide variation observed in different studies is due to different study designs, limited sample size, lack of standardized diagnostic criteria, inclusion of only selected types of ICU patients, different inclusion and exclusion criteria, and/or failure to include comprehensive and rigorous statistical analysis. 
Table 1. Diagnosis of CMV end organ disease [18]

\begin{tabular}{|c|c|c|}
\hline Site & Clinical Sample & Preferred diagnostic test \\
\hline Lung & $\begin{array}{l}\text { BAL, Lung biopsy from patient having signs } \\
\text { and symptoms of pulmonary disease }\end{array}$ & $\begin{array}{l}\text { Viral culture, IHC, } \\
\text { histopathology, in situ } \\
\text { hybridization }\end{array}$ \\
\hline $\begin{array}{l}\text { Gastro intestinal } \\
\operatorname{tract}(\text { GIT) }\end{array}$ & $\begin{array}{l}\text { Biopsy from GIT in a patient having signs and } \\
\text { symptoms of G.I disease along with mucosal } \\
\text { lesions on endoscopy }\end{array}$ & $\begin{array}{l}\text { Viral culture, IHC, } \\
\text { histopathology, in situ } \\
\text { hybridization }\end{array}$ \\
\hline Liver & $\begin{array}{l}\text { Liver biopsy in a patient with deranged liver } \\
\text { function test and other apparent causes of } \\
\text { hepatitis have been ruled out }\end{array}$ & $\begin{array}{l}\text { Viral culture, IHC, } \\
\text { histopathology, in situ } \\
\text { hybridization }\end{array}$ \\
\hline Pancreas & Pancreatic biopsy & $\begin{array}{l}\text { Histopathologically s/o CMV } \\
\text { infection and Viral culture, IHC, } \\
\text { in situ hybridization }\end{array}$ \\
\hline $\begin{array}{l}\text { Central nervous } \\
\text { system }\end{array}$ & $\begin{array}{l}\qquad \quad \text { CSF } \\
\bullet \quad \text { Brain biopsy } \\
\text { ( In patient having signs and symptoms of } \\
\text { CNS disease) }\end{array}$ & $\begin{array}{l}\text { - Viral culture or PCR } \\
\text { - Viral culture, IHC, } \\
\text { histopathology, in situ } \\
\text { hybridization }\end{array}$ \\
\hline Retina & \multicolumn{2}{|c|}{ Ophthalmologically features typical of CMV retinitis } \\
\hline Kidneys & $\begin{array}{l}\text { Kidney biopsy in a patient having abnormal } \\
\text { renal function test }\end{array}$ & $\begin{array}{l}\text { Histopathology s/o CMV } \\
\text { infection and Viral culture, IHC, } \\
\text { in situ hybridization }\end{array}$ \\
\hline Heart & Biopsy from patient with myocarditis & $\begin{array}{l}\text { Histopathology s/o CMV } \\
\text { infection and Viral culture, IHC, } \\
\text { in situ hybridization }\end{array}$ \\
\hline Other categories & $\begin{array}{l}\text { Biopsy with signs and symptoms related to } \\
\text { organ of involvement with other causes ruled } \\
\text { out }\end{array}$ & $\begin{array}{l}\text { Histopathology s/o CMV } \\
\text { infection and Viral culture, IHC, } \\
\text { in situ hybridization }\end{array}$ \\
\hline
\end{tabular}

controversy and there are no uniform guidelines

It has further been observed that CMV infection is associated with adverse clinical outcomes in these critically ill patients. Many studies have shown the importance of CMV infection in such patients [1217]. Presence of CMV infection in critically ill ICU patients led to increased length of ICU stay and increased duration of mechanical ventilation as compared to patients negative for CMV infections even when both the groups had similar disease severity $[8,12,13]$ Nosocomial infections were also significantly higher in patients positive for CMV as compared to non CMV patients [15]. The rates of renal failure and steroid therapy were also higher in CMV positive groups $[8,14]$. CMV infected patients also had higher mortality as compared to CMV negative patients $[12,15]$. Thus many different studies have highlighted the importance of CMV infection in ICU patients [8,12-17].

\section{Diagnosis}

Diagnosis of CMV infection in such critically ill but immunocompetent cases is another area of available. An ideal diagnostic test should be able to detect active CMV infection and differentiate it from CMV disease. The test should be simple to perform and it should also give rapid and reliable test results. It should further be able to identify the CMV infection as early as possible and be useful in monitoring the progress of CMV disease.

There is still a diagnostic dilemma between active CMV infection and CMV disease; hence advanced diagnostic procedures are initiated to confirm active CMV disease. CMV infection is defined as isolation of CMV (viral culture) or detection of CMV proteins (pp65) or nucleic acid by polymerase chain reaction (PCR) from blood or other clinical samples [18].

CMV can cause end organ disease in various body organs/tissues. The disease is confirmed by clinical findings suggestive of the organ involvement plus demonstration of CMV by viral isolation, histopathologic testing, immunohistochemical analysis, or in situ hybridization from the relevant clinical sample obtained from the site of involvement. Detection of CMV by PCR alone is too 
Table 2. Clinical manifestations of CMV in immunocompetent patients

\begin{tabular}{|c|c|c|c|c|}
\hline Clinical disease & $\begin{array}{l}\text { Comorbid } \\
\text { condition }\end{array}$ & $\begin{array}{l}\text { patients diagnosed } \\
\text { with } \mathrm{CMV} / \text { no. of } \\
\text { patients reviewed } \\
(\%)\end{array}$ & Diagnostic test used & Reference \\
\hline Mediastinitis & $\begin{array}{l}\text { Cardiac surgery } \\
\text { Blood transfusion }\end{array}$ & $29 / 115(25.2)$ & $\begin{array}{l}\text { Viral culture of blood and } \\
\text { urine }\end{array}$ & 27 \\
\hline Pneumonia & $\begin{array}{l}\text { Mechanical } \\
\text { ventilation }\end{array}$ & $25 / 86(29)$ & $\begin{array}{l}\text { Histopathology of lung } \\
\text { tissue }\end{array}$ & 28 \\
\hline $\begin{array}{l}\text { Dyspepsia and } \\
\text { other GI symptoms }\end{array}$ & None & $14 / 33(42 \%)$ & IHC against pp65 & 29 \\
\hline Colitis & $\begin{array}{l}\text { Advanced age, } \\
\text { post surgical } \\
\text { interventions }\end{array}$ & $\begin{array}{l}\text { Meta analysis and } \\
\text { case reports }\end{array}$ & $\begin{array}{l}\text { Histopathology of GIT } \\
\text { tissue biopsy. } \\
\text { +ve pp } 65 \text { antigenemia } \\
\text { +ve CMV serology }\end{array}$ & 30,31 \\
\hline $\begin{array}{l}\text { Thrombotic } \\
\text { complication } \\
\text { (portal vein } \\
\text { thrombosis) } \\
\end{array}$ & $\begin{array}{l}\text { Prothrombotic } \\
\text { disorder } \\
\text { Cancer, cirrhosis, } \\
\text { hepatitis } \\
\end{array}$ & Case reports & $\begin{array}{l}\text { +ve CMV serology(IgG } \\
\text { and } \operatorname{IgM}) \text {, other apparent } \\
\text { causes ruled out }\end{array}$ & 32 \\
\hline Meningitis & None & Case report & CMV DNA in CSF & 33 \\
\hline $\begin{array}{l}\text { Pericardial } \\
\text { effusion }\end{array}$ & $\begin{array}{l}\text { Pericardial } \\
\text { effusion } \\
\text { Congenital heart } \\
\text { disease }\end{array}$ & $5 / 33(15)$ & $\begin{array}{l}\text { Viral Culture, +ve } \\
\text { serology }\end{array}$ & 34 \\
\hline $\begin{array}{l}\text { Myopericarditis } \\
\text { and hepatitis }\end{array}$ & None & Case reports & $\begin{array}{l}\text { +ve CMV serology(IgG } \\
\text { and IgM), other apparent } \\
\text { causes ruled out } \\
\text { In one report +ve pp65 Ag } \\
\text { in PBL }\end{array}$ & 35,36 \\
\hline
\end{tabular}

sensitive and insufficient for confirming CMV disease [18].

The conventional methods for the diagnosis of $\mathrm{CMV}$ infection/disease are viral isolation by viral culture, serology which includes CMV specific antigen and antibody detection, and molecular method for detection of viral DNA from blood and other clinical specimens. Viral isolation done by either tissue culture or shell vial culture is the most specific diagnostic test and until now was regarded as the gold standard, but it is labor intensive and the results are available after a minimum of one to two days. Hence other rapid methods such as detection of pp65 antigen from peripheral blood leucocytes and PCR from blood or peripheral blood leucocytes (PBL) for detection of CMV DNA are preferred for diagnosis.

CMV antigenemia has appeared as a major advancement in the diagnosis of both active CMV infection and CMV disease. It has a definite advantage over shell vial culture and is equally sensitive and specific compared to CMV DNA detection for diagnosis of CMV infection $[19,20]$. It is a rapid test with the results being available in four to five hours of processing time [19]. A blood sample is treated to separate the polymorpho nuclear leucocyte (PMNL) fraction, which is then placed on a microscopy slide, incubated to facilitate cell adherence, then fixed with either acetone or fomalin and stained by indirect immunofluorescence to look for nuclear or perinuclear staining of the cells seen in case of CMV infection [19,20]. The limitations of the test, however, are that it is labor intensive, immediate processing is required, and the test results are dependent on the number of leucocytes evaluated. Furthermore, the interpretation of the test is subjective and a skilled microscopist is required to accurately interpret the results.

Molecular methods for the detection of CMV DNA from various samples are also being widely used. PCR is a highly sensitive method because of its ability to detect minute amounts of nucleic acid in various clinical samples. A study regarding the use of nested PCR using PBL resulted in a sensitivity and specificity of $100 \%$ for detection of CMV infection.

[21]. The limitation of the assay is that it is not well standardized. Hence, for increasing 
Figure 1. Systematic approach for diagnosing acute CMV infection

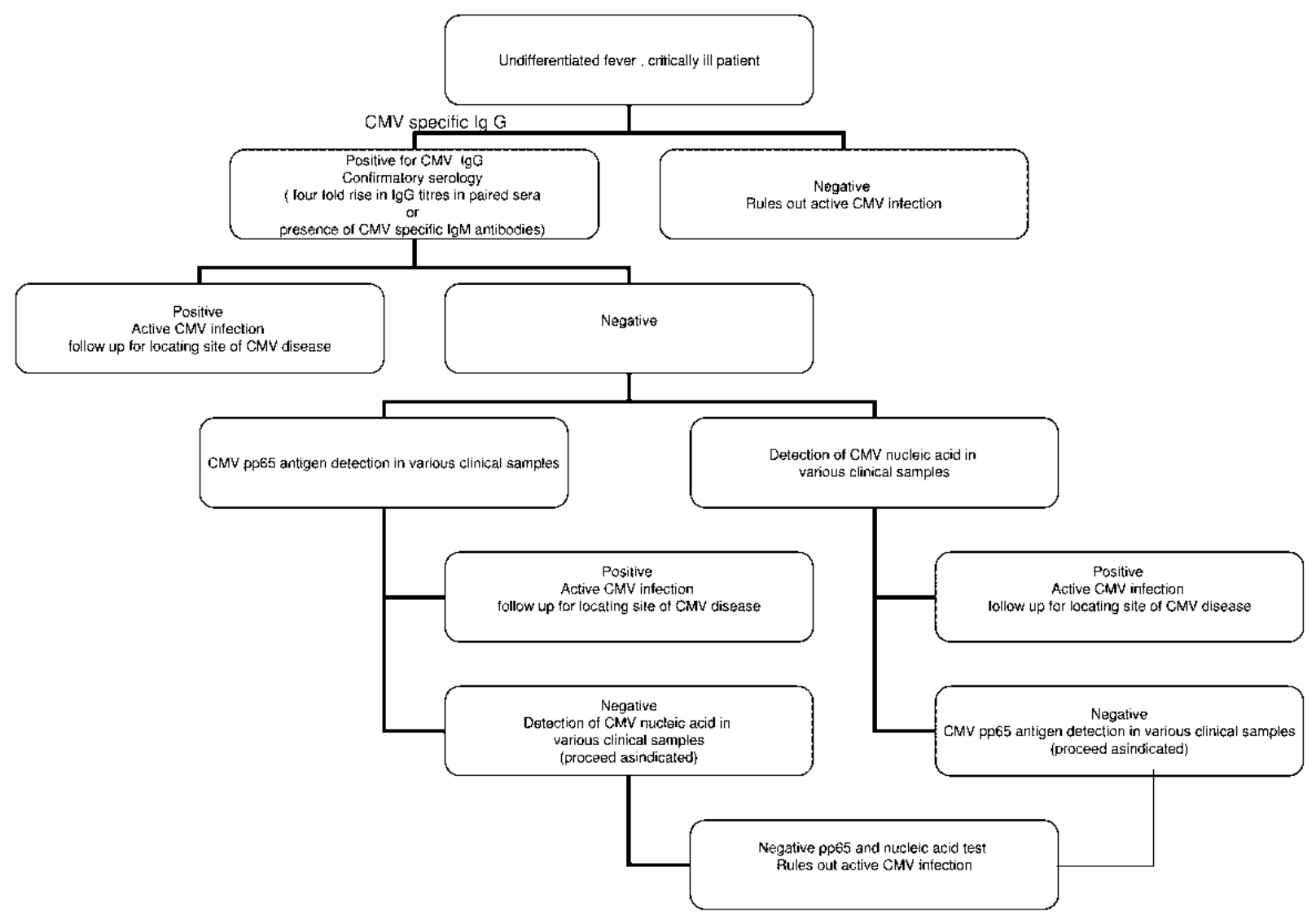

interlaboratory comparability of standard reference materials, commercially available systems must be used. These are costly and therefore not practical in basic laboratories [20,21,22]. The role of viral serology in diagnosing CMV infection in critically ill immunocompetent patients is significant as most CMV infections are as a result of reactivation of the virus and not primary infection. In most cases, therefore, CMV specific IgG antibodies would be present. The presence of CMV specific Ig $\mathrm{M}$ antibodies and four fold rise of Ig $\mathrm{G}$ titers in paired sera help to confirm active CMV infection.

The relevant diagnostic test for identifying CMV infection in critically ill patients would be the presence of CMV specific Ig $\mathrm{G}$ antibodies and confirmatory serology or detection of CMV antigen ( pp65) or DNA ( by PCR) from blood and other clinical samples (Figure 1).

To confirm the presence of CMV disease clinical findings should be supplemented with diagnostic tests such as the demonstration of CMV from the suspected organ/site by histopathological evaluation (Table1). Cytomegalovirus produces typical cytopathic effects which include cytomegaly, i.e., large cells around $25-35 \mu \mathrm{m}$ containing basophilic intranuclear inclusions which are sometimes surrounded by a clear halo and are usually associated with clusters of intracytoplasmic inclusions [23].

Immunohistochemistry using monoclonal antibodies and in situ DNA hybridization on the biopsied tissue increases the sensitivity of histopathologic CMV diagnosis.

Determination of CMV viral load by quantitative methods should be done before starting therapy. This helps in monitoring the progress of CMV disease. Conventional assays for quantitating CMV include the traditional plaque assay, determination of $50 \%$ tissue culture infective dose (TCID 50), and modified tissue culture methods. These methods are timeconsuming, laborious and are less sensitive. Hence 
Table 3. Treatment options for CMV infection and disease [35,36,37]

\begin{tabular}{|c|c|c|c|}
\hline Drug & MOA & Side effects & Beneficial role \\
\hline $\begin{array}{l}\text { Ganciclovir }(\mathrm{GCV}) \text { and } \\
\text { valganciclovir (VGCV) }\end{array}$ & Nucleoside analogue & $\begin{array}{l}\text { Bone marrow } \\
\text { suppression, } \\
\text { neuropsychiatric } \\
\text { disturbance }\end{array}$ & $\begin{array}{l}\text { GCV :DOC for prophylaxis, } \\
\text { preemptive therapy and treatment } \\
\text { of CMV disease }\end{array}$ \\
\hline $\begin{array}{l}\text { Acyclovir (ACV) and } \\
\text { Valacyclovir (VACV) }\end{array}$ & Nucleoside analogue & $\begin{array}{l}\text { CNS side effects } \\
\text { (tremors, hallucination, } \\
\text { convulsion), allergic } \\
\text { reactions }\end{array}$ & $\begin{array}{l}\text { Not studied for preemptive } \\
\text { therapy or treatment } \\
\text { Can be used for Prophylaxis }\end{array}$ \\
\hline Cidofovir & Nucleotide analogue & $\begin{array}{l}\text { Nephrotoxic } \\
\text { thrombocytopenia } \\
\text { ophthalmological or } \\
\text { neurological toxicity }\end{array}$ & $\begin{array}{l}\text { Poor results for Preemptive } \\
\text { therapy and treatment of CMV } \\
\text { disease }\end{array}$ \\
\hline Foscarnet & Pyrophosphate analogue & $\begin{array}{l}\text { Nephrotoxic, } \\
\text { paraesthesia, electrolyte } \\
\text { disturbance }\end{array}$ & $\begin{array}{l}2^{\text {nd }} \text { line drug for preemptive } \\
\text { therapy or treatment of CMV } \\
\text { disease } \\
\text { DOC in cases of neutropenia or } \\
\text { resistance to GCV }\end{array}$ \\
\hline $\begin{array}{l}\text { Maribavir } \\
\text { ( investigational) }\end{array}$ & $\begin{array}{l}\text { Benzimidazole riboside } \\
\text { compound }\end{array}$ & & $\begin{array}{l}\text { Prophylaxis and treatment of } \\
\text { CMV resistant to GCV }\end{array}$ \\
\hline $\begin{array}{l}\text { Carimune, Gamimune, } \\
\text { Gammagard S/D, Gammar P, } \\
\text { Polygam S/D }\end{array}$ & $\begin{array}{l}\text { Random donor } \\
\text { immunoglobulins }\end{array}$ & & $\begin{array}{l}\text { Immunomodulatory, can be used } \\
\text { for prophylaxis or in treatment of } \\
\text { CMV disease in combination } \\
\text { with antivirals }\end{array}$ \\
\hline CytoGam & $\begin{array}{l}\text { CMV hyper } \\
\text { immunoglobulin }\end{array}$ & & $\begin{array}{l}\text { Immunomodulatory, can be used } \\
\text { for prophylaxis or in treatment of } \\
\text { CMV disease in combination } \\
\text { with antivirals }\end{array}$ \\
\hline $\mathrm{CD}^{+}$CMV CTLs & $\begin{array}{l}\text { Adoptive } \\
\text { immunotherapy }\end{array}$ & & $\begin{array}{l}\text { Shown to be effective as } \\
\text { prophylaxis or preemptive } \\
\text { therapy }\end{array}$ \\
\hline
\end{tabular}

newer methods such as quantitative antigen detection assays and molecular methods can be used to quantitate $\mathrm{CMV}$ in various clinical samples. These are relatively simpler and more sensitive methods $[24,25]$.

\section{Clinical manifestation}

Clinical spectrum of CMV disease ranges from a mild mononucleosis-like syndrome to very severe multivisceral involvement. All types of visceral involvement have been observed even in immunocompetent persons. The clinical syndromes observed in such patients include interstitial pneumonitis, hematological disorders, hepatitis, gastroenteritis, colitis, myocarditis, meningoencephalitis, uveitis, retinitis and others. Such severe manifestations of CMV are rare in immunocompetent hosts without any identifiable risk factors. Critically ill patients admitted in ICUs are at increased risk for such multivisceral involvement as there is usually an identifiable risk factor which is present in such patients. The common risk factors present would include presence of mechanical ventilation, sepsis, burns, recipients of blood transfusion, trauma, post surgical patients, chronic renal failure, steroid therapy, and extremes of age.

Contrary to the traditional belief that CMV infection in immunocompetent but critically ill patients follows a self-limited course, are considerable investigations that report increased morbidity and mortality as a result of CMV in such cases [12-17].

CMV is ubiquitously present in the body [26]. CMV establishes latency in various organs; thus any site is susceptible for reactivation of the disease (Table2). The type of organ system affected by CMV 
is different in different patient groups. Lungs act as reservoir in cases of latent $\mathrm{CMV}$ infection and thus act as the most consistent site for its reactivation. Domart et al. diagnosed CMV infection in 29 patients with mediastinitis among 115 immunocompetent patients after cardiac surgery. The peri-operative blood transfusion of non leukocyte depleted blood was considered to be responsible for CMV seroconversion [27].

Papazian et al. reviewed 2,785 patients admitted to ICUs during the years 1989-1994. Sixty autopsies and 26 open lung biopsies were performed in nonimmunosuppressed patients with acute respiratory failure and ventilator associated pneumonia. CMV as a causative agent of pneumonia was demonstrated in 25 of them and all these patients had a more severe hypoxemia as compared to others [28].

Clinically significant gastrointestinal manifestations are seen as a result of CMV in critically ill immunocompetent patients. Halme et al. demonstrated that CMV was detected in $71 \%$ of the patients with liver transplants who had gastrointestinal symptoms, $45 \%$ with chronic liver disease, $20 \%$ with acute liver disease, and $45 \%$ of otherwise immunocompetent patients with dyspepsia. CMV was detected by immunohistochemistry technique using monoclonal antibodies against pp65 antigen of CMV on gastric biopsies [29].

Although CMV colitis is not a common clinical presentation, it has been detected in otherwise immunocompetent patients. These patients usually experience diarrhoea as a result of colitis. It is more common in extremes of age, presence of immunomodulating conditions such as diabetes mellitus, renal failure, malignancies, and patients who have had post surgical interventions [30,31].

Thrombotic complications have also been associated with CMV infection in immunocompetent individuals. Some viral infections are known to cause hemostatic abnormalities which could be as severe as disseminated intravascular coagulation. CMV mediated portal venous thrombosis has been reported probably as a consequence of acute hepatitis. Liver function abnormalities are comparatively common in symptomatic individuals as $\mathrm{CMV}$ is a hepatotropic virus. Though CMV commonly causes hepatitis it can be proved only if virus is detected on liver biopsies by detection of inclusion bodies or by immunohistochemical staining [32].

CNS manifestations are very common in immunocompromised patients but there have been reports of meningitis and other CNS manifestations as a result of CMV even in immunocompetent patients[33]. Cardiac involvement, though rare, has also been observed in immunocompetent adults. In a study of 57 patients with pericardial effusion, Campbell et al. found five patients with CMV pericardial disease. In three of these patients underlying risk factors were present [34]. There have also been case reports of CMV associated myocarditis and hepatitis $[35,36]$.

The list is not exhaustive and there are still other case reports and case series of CMV mediated disease. The purpose of mentioning these case reports was to highlight the fact that CMV can virtually affect any organ even in otherwise immunocompetent individuals. Hence it should be kept in mind as a differential diagnosis in critically ill ICU patients presenting with fever.

\section{Treatment}

The use of antiviral treatment for CMV has proven to be of benefit in immunosuppressed individuals, but there is a scientific debate over the issues of treating CMV infection in cases of immunocompetent individuals. The major therapeutic strategies used by clinicians are prophylactic or preemptive therapy. The goal is to prevent the development of end stage organ disease. The first step is to start the therapy universally (prophylactic therapy) and the next is to give antivirals to specific high-risk patients (preemptive therapy). The basic principle of preemptive therapy is to initiate antivirals for patients displaying viremia early in the clinical course to halt the progression to end organ disease [37].

The drugs available for treating CMV include ganciclovir (GCV) and valganciclovir (VGCV), acyclovir (ACV) and valacylovir (VACV), Mirabivir, foscarnet and cidofovir Table 3). Most of the studies involving these treatments have been performed in immunocompromised patients and transplant recipients $[37,38,39]$. There is a need to perform multicentre experimental studies using these antivirals in a large number of critically ill immunocompetent patients to come to a conclusion regarding their beneficial role in such cases.

One experimental study demonstrated that ganciclovir prevented murine CMV reactivation and the development of pulmonary fibrosis in immunocompetent mice with sepsis [40]. The improvement seen in some patients in a few other studies could also be due to the self-limiting nature of 
CMV disease and therefore the credit cannot be given to antivirals with certainty.

Resistance to these drugs has been documented on prolonged usage, as seen in HIV patients. Antivirals have to be used only for a limited duration in immunocompetent patients to tide over the acute phase. In such circumstances resistance to these antivirals is not usually a problem. Targeting antivirals in all critically ill patients in the ICU might be impractical as these antivirals frequently have bone marrow suppression as one of their major side effects. There has been no consensus regarding the therapeutic protocol to be used in such patients. Many clinicians believe that CMV is self-limiting in immunocompetent patients and the critically ill patients should not be exposed to the adverse effects associated with these antivirals. But there have been considerable reports of adverse clinical outcomes in such critically ill immunocompetent patients who have associated risk factors. Hence the correct approach would be to treat critically ill patients who are at higher risk of developing CMV disease.

\section{Conclusion}

CMV reactivation in critically ill nonimmunosuppressed patients leads to increased mortality and morbidity in terms of increased ICU stay, longer duration of mechanical ventilation, and higher rates of nosocomial infections. Though CMV can virtually affect any organ system, lungs appear to be the most common organ of involvement. There are no overt signs and symptoms of active CMV disease and most episodes start with fever. The intensivists should thus be aware of the possibility of CMV reactivation in otherwise immunocompetent patients admitted in the ICU who have associated risk factors such as mechanical ventilation, severe sepsis, or blood transfusion. Advanced diagnostic procedures should be initiated to identify active CMV infection and disease as early as possible. No definitive conclusions can be made regarding the beneficial effect of antiviral therapy in immunocompetent individuals as there are very few experiences and further clinical trials are required to reach definitive conclusions. The decision to initiate antivirals should be based on clinical assessment. Patients who have associated risk factors should preferably be given antiviral treatment.

\section{References}

1. Crough T and Khanna R (2009) Immunobiology of human cytomegalovirus: from bench to bedside. Clin Microbiol Rev 22: 76-98.

2. Emery VC (2001) Investigation of CMV disease in immunocompromised patients. J Clin Pathol 54: 84-88.

3. Mocarski ES Jr (2004) Immune escape and exploitation strategies of cytomegaloviruses: impact on and imitation of the major histocompatibility system. Cell Microbiol 6: 707717.

4. Cook CH, Trgovcich J, Zimmerman PD, Zhang Y, Sedmak DD (2006) Lipopolysaccharide , tumor necrosis factor alpha , or interleukin - $1 \beta$ triggers reactivation of latent cytomegalovirus in immunocompetent mice. J of Virol 80: 9151-9158.

5. Hummel $M$ and Abecassis MM (2002) A model for reactivation of CMV from latency. J Clin Virol 25: s123136.

6. Rennekampff HO and Hemprecht K (2006) Cytomegalovirus infection in burns: a review. J of Med Microbiol 55: 483-487.

7. MC Guedes MI, Risdahl JM, Wiseman B, Molitor TW (2004) Reactivation of porcine cytomegalovirus through allogeneic stimulation. J Clin Microbiol 42: 1756-1758.

8. Muller LV, Klemn A, Weiss M, Schneider M, SugerWiedeck H, Durmus N, Hampl W, Mertens T ( 2006) Active cytomegalovirus infection in patients with septic shock. Emerg Infect Dis 12: 1517-1522.

9. Grundy JE (1990) Virologic and pathogenetic aspects of cytomegalovirus infection. Rev Infect Dis 12: S 711-719.

10. Squizzato A, Gerdes VEA, Buller HR ( 2005) Effects of human cytomegalovirus infection on the coagulation system. Thromb Haemost 93: 403-410.

11. Bruggeman CA, Li F, Stals FS (1995) Pathogenicity: animal models. Scand J Infect Dis Suppl 99: 43-50.

12. Wiener-Well Y, Yinnon AM, Singer P, Hersch M (2006) Reactivation of cytomegalovirus in critically sick patients. IMAJ 8: 583-584

13. Heininger A, Gerhard J, Corinna E, Thomas Nm Klaus U ,Klaus H (2001) Human cytomegalovirus infections in nonimmunosuppressed critically ill patients. Crit care medicine 29: 541-547

14. Limaye AP, Kirby KA, Rubenfeld GD, Leisenring WM, Bulger EM, Neff MJ, Gibran NS, Huang ML, Santo Hayes TK, Corey L, Boeckh M (2008) Cytomegalovirus reactivation in critically ill immunocompetent patients. JAMA 300: 413-422.

15. Jaber S, Chanques G, Borry J, Souche B, Verdier R, Perrigault PF, Eledjam JJ (2005) Cytomegalvirus infection in critically ill patients. Chest 127: 233-241.

16. Osawa R and Singh N (2009) Cytomegalovirus infection in critically ill patients: a systematic review. Crit care 13: R68.

17. Rafailidis PI, Mourtzoukou EG, Varbobitis IC, Falagas ME (2008) Severe cytomegalovirus infection in apparently immunocompetent patients: a systematic review. Virology Journal 5: 47.

18. Ljungman P, Griffiths P, Paya C (2002) Definitions of cytomegalovirus infection and disease in transplant recipients. Clin Infect Dis 34: 1094-1097

19. Erice A,Holm MA, Gill PC, Henry S, Dirksen C, Dunn D, Hillam RP , Balfour HH (1992)Cytomegalovirus (CMV) antigenemia assay is more sensitive than shell vial cultures 
for rapid detection of CMV in polymorphonuclear blood leukocytes. J of Clin Microbiol 30: 2822-2825.

20. Cariani E, Pollara CP, Valloncini B, Perendin F, Bonganti C ,Manca N (2007) Relationship between pp65 antigenemia levels and real time quantitative DNA PCR for human cytomegalovirus (HCMV) management in immunocompromised patients. BMC Infects Dis 7: 138.

21. Zhang S, Zhou YH, LI L, Hu Y (2010) Monitoring human cytomegalovirus infection with nested PCR: comparison of positive rates in plasma and leucocytes and with quantitative PCR. Virol J 7: 73.

22. Muller L, Hampl W, Hinz J, Meisel H, Reio A, Engelman E (2003) High Variability between Results of Different InHouse Tests for Cytomegalovirus (CMV) Monitoring and a Standardized Quantitative Plasma CMV PCR Assay. J of Clin Microbiol 40: 2285-2287.

23. Hinnant KL, Rotterdam HZ, Bell ET, Tapper ML (1986) Cytomegalovirus infection of the alimentary tract: a clinicopathological correlation. Am J Gastroenterol 81: 944950.

24. Boeckh $M$ and Boivin $G$ (1998) Quantitation of Cytomegalovirus: Methodologic aspects and clinical application. Clin Microbiol Rev 11: 533-554.

25. Gimeno C, Solano C, Latorre JC, Hernández-Boluda JC, Clari MA, Remigia MJ, Furió S, Calabuig M, Tormo N, Navarro D (2008) Quantification of DNA in plasma by an automated real-time PCR assay (cytomegalovirus PCR kit) for surveillance of active cytomegalovirus infection and guidance of preemptive therapy for allogeneic hematopoietic stem cell transplant recipients. J Clin Microbiol 46: 33113318.

26. Hendrix RMG, Wagenaar M, Slobbe RL, Bruggeman CA (1997) Widespread presence of cytomegalovirus DNA in tissues of healthy trauma victims. J Clin Pathol 50: 59-63.

27. Domart Y, Trouillet JL, Fagon JY, Chastre J, Brun-Vezinet F, Gibert C (1990) Incidence and morbidity of cytomegaloviral infection in patients with mediastinitis following cardiac surgery. Chest 97: 18-22.

28. Papazian L, Fraisse A, Garbe L, Zandotti C, Thomas P, Saux P, Pierrin G, Gouin F (1996) Cytomegalovirus: an unexpected cause of ventilator-associated pneumonia. Anesthesiology 84: 280-287.

29. Halme L, Lempinen M, Arola J, Sarkio S, Höckerstedt K, Lautenschlager I (2008) High frequency of gastroduodenal cytomegalovirus infection in liver transplant patients. APMIS 116: 99-106.

30. Van Gool S, Van Casteren L, Buchel O, Frans E, Dedeurwaerdere F, Van Olmen A, D'Haens G, Moons V, Christiaens P (2008) Cytomegalovirus colitis in an apparently immunocompetent host after biliopancreatic diversion for obesity. Acta Gastroenterol Belg 71: 423-426.

31. Galiatsatos P, Shrier I, Lamoureux E, Szilagyi A (2005) Meta-analysis of outcome of cytomegalovirus colitis in immunocompetent hosts. Dig Dis Sci 50: 609-616.

32. Squizzato A, Ageno W, Cattaneo A, Brumana N (2007) A Case Report and literature review of portal vein thrombosis associated with Cytomegalovirus infection in immunocompetent patients. Clin Infect Dis 44: e13-16.

33. Rafailidis PI, Kapaskelis A, Falagas ME (2007) Cytomegalovirus meningitis in an immunocompetent patient. Med Sci Monit 13: CS107-109.

34. Campbell PT, Li JS, Wall TC, O'Connor CM, Van Trigt P, Kenney RT, Melhus O, Corey GR (1995) Cytomegalovirus pericarditis : a case series and review of the literature. Am J Med Sci 309: 229-234.

35. Zabiaurre L, Zapata E, Biyanda L, Castillo M, Oyarzabal I, Gutierrez-Stampa MA, Cosme A (2007) Cytomegalovirus hepatitis and myopericarditis. World J Gastroenterol 13: 647-648

36. Fernández-Ruiz M, Muñoz-Codoceo C, López-Medrano F, Faré-García R, Carbonell-Porras A, Garfia-Castillo C, Muñoz-Gómez R, Aguado-García JM (2008) Cytomegalovirus Myopericarditis and Hepatitis in an Immunocompetent Adult: S uccessful Treatment with Oral Valganciclovir. Inter Med 47: 1963-1966.

37. Griffiths PD (2002) The treatment of cytomegalovirus infection. J of antimicrobial chemotherapy 49: 243-53.

38. Razonable RR (2008) Cytomegalovirus infection after liver transplantation: current concepts and challenges. World $\mathrm{J}$ Gastroenterol 14: 4849-4860.

39. Meyer E, Boland GJ, Verdonck LF (2003) Prevention of cytomegalovirus disease in recipients of allogeneic stem cell transplants. Clin Microbiol Rev16: 647-657.

40. Forster MR, Trgovcich J, Zimmerman P, Chang A, Miller C, Klenerman P, Cook CH (2010) Antiviral prevention of sepsis induced cytomegalovirus reactivation in immunocompetent mice. Antiviral Res 85: 496-503.

\section{Corresponding Author}

Dr Manisha Jain

Assistant Professor

Department of Microbiology

G. B. Pant Hospital

Delhi, India

Telephone: 9718599065

Email: manisha_jain29@yahoo.com

Conflict of interests: No conflict of interests is declared. 